\title{
Variations in Rainfall Timing and Changes in the Leading Edge of Hurricane Katrina (2005) During Gulf Coast Landfalls
}

\author{
Corene J Matyas* \\ Department of Geography, University of Florida, USA
}

Submission: November 02, 2020; Published: November 16, 2020

*Corresponding author: Corene J Matyas, Department of Geography, University of Florida, 3141 Turlington Hall, Gainesville, Florida 32611, USA

\begin{abstract}
The leading edge of a tropical cyclone (TC) brings gusty winds and rainfall to locations many hours prior to the arrival of the storm's eyewall, especially when the storm is large. Defining the leading edge of a TC's rain field is a complex task as the storm begins to interact with the land surface and more dense continental air masses. This study measures the outer rainbands in Hurricane Katrina (2005) as detected by radar-based data around its Gulf Coast landfalls. The objectives are to 1) determine the hour when rainfall begins along the coast and relate that to storm position and the timing of warnings, and 2) track the position of the leading edge of the outermost rainband over the landfalling period. Rainfall started an average of 12 hours prior to Katrina's landfall when the storm was $353 \mathrm{~km}$ away from the 10 locations that were analyzed. Rainfall began prior to the arrival of gale-force winds at some locations. Five different rainbands containing 40dBZ reflectivity values were tracked over a $20 \mathrm{~h}$ period. Earlier bands propagated outwards while later rainbands did not, yet they grew in length. The area occupied by the storm had at least $60 \mathrm{~mm}$ of total precipitable water, with a $1 \mathrm{~mm}$ decrease each $10 \mathrm{~km}$ occurring on the western side of the storm where two bands dissipated. Future research should identify similar moisture gradients to better assess their role in enhancing or inhibiting rainband development and determine rainfall onset times for more TCs.
\end{abstract}

Keywords: Outer rain band; Landfall; Radar reflectivity; GIS; Rainfall

Abbreviations: TC: Tropical Cyclone; TPW: Total Precipitable Water; GIS: Geographic Information System; R17: Radius of 17ms ${ }^{-1}$ Winds; NARR: North American Regional Reanalysis; NHC: National Hurricane Center; WSR-88D: Weather Surveillance Radar 1988 Doppler

\section{Introduction}

At the time, Hurricane Katrina (2005) was estimated to be the costliest natural disaster to impact the U.S. and was also one of the most intense hurricanes in terms of its minimum central pressure [1]. Although the majority of damage and deaths resulted from record storm surge along the Mississippi coast and failure of levees in Louisiana, it also brought copious rainfall to several locations. Predicting the time and location of landfall is an important task, and much of the research on tropical cyclone (TC) rainbands explores convective cells within the eyewall given the importance of processes in this region for storm intensity $[2,3]$. Yet heavy rainfall, gusty winds, and storm surges begin hours prior to the storm's center crossing land. Thus, it is also important to assess the leading edge of the storm to determine when conditions will deteriorate to the point that people should have already evacuated or be sheltering in place. Convective cells in the outer rainbands can bring high rain rates, gusty winds, and tornadoes can form within these cells as the heavy rain and cool downdrafts transfer momentum from above the boundary layer down to the surface. The hour of issuance for a TC warning conveys the time remaining until gale-force winds arrive, yet the time of TC rainfall arrival is not formally conveyed in the manner.

Willoughby et al. [4] found that one or two rainbands typically exist outside of the core of the storm at the boundary between the TC and the environment that surrounds it. The outer rainband tends to be located between $100-200 \mathrm{~km}$ [5] outward of $150 \mathrm{~km}$ [6], $200-300 \mathrm{~km}$ [7], or more than $500 \mathrm{~km}$ [8] from the storm center. These rainbands are more cellular in shape when compared with those in the storm's core $[9,10]$ and are not as sensitive to changes 
in storm intensity [11]. Rainbands can be stationary relative to the storm center, while moving bands rotate cyclonically around the center. Outer rainbands tend to propagate outward. However, [12] observed a rainband at $130 \mathrm{~km}$ from the simulated storm center moving cyclonically and radially inward while one at $155 \mathrm{~km}$ moved radially outward likely due to asymmetric outflow from convective downdrafts.

Copious amounts of atmospheric moisture must be advected horizontally into the TC to the maintain the production of precipitation. Trenberth et al. [13] found that for Hurricane Katrina, $62 \%$ of rainfall came from moisture convergence outside of the $400 \mathrm{~km}$ radius. By accounting for TPW, [14] found a stronger correlation between volumetric rain and maximum wind speed. Research by [15] and [16] found that TCs can grow larger in size and produce more rainfall in their outer rainbands when high values of relative humidity occur in the environment outside of the TC. An analysis of Typhoon Bobbie (1992) by [17] observed that the influx of air with total precipitable water (TPW) values over $50 \mathrm{~mm}$ aided the growth of convective clouds in the outer rainbands, while convection diminished once TPW values fell below $50 \mathrm{~mm}$. In a study of TCs making landfall over the U.S. Gulf coastline, [18] found that TCs approaching the central Gulf coast, including Hurricane Katrina (2005), had median TPW values of $50 \mathrm{~mm}$ on both the left and right sides of the storm, and values remained high during the day preceding landfall.

This geographically-based case study was motivated by the analysis of Hurricane Frederic (1979) conducted by [19]. They made the first digital recording of a landfalling hurricane and measured the position and motion of rainbands according to reflectivity values. The current study employed a Geographic Information System (GIS) to examine rainfall and the spatial patterns of outer rainbands associated with Hurricane Katrina (2005) around its Louisiana and Mississippi landfalls. Two perspectives were taken. The first examined rainfall using fixed locations on the coastline, with the other using a storm-relative approach. The objectives were to

a) determine the hour when rainfall begins at coastal locations that received rain prior to landfall, and

b) track the position of the leading edge of the outermost rainband(s) until data were no longer available from the radar located at Slidell, Louisiana.

The start time of rainfall at ten locations along the coast was compared with measures of the TC's wind field and timing of hurricane and tropical storm warnings. Then, rainband orientation and position relative to the storm center were determined over a $20 \mathrm{~h}$ period to facilitate the calculation of propagation speed and reveal how the outer edge of the TC changed during interaction with land. Precipitable water values were examined to determine the moisture conditions present where the bands form and decay.

\section{Materials and Methods}

\section{Storm summary}

At the time, Hurricane Katrina had the third lowest pressure ever noted at landfall and was the costliest hurricane to strike the United States [20]. Despite its well-known impacts from storm surge and storm wind, it also produced one of the top five largest one-day precipitation events in June, July, or August [21]. Rainfall exceeded 10 inches at six locations across Louisiana. Thus, its rainbands warrant examination. At 1800UTC 28 Aug., Katrina had attained its peak intensity, with maximum sustained wind speeds of $77 \mathrm{~ms}^{-1}(150 \mathrm{kt}$ ). At this time, it was about $315 \mathrm{~km}$ south of the mouth of the Mississippi River [22], which is co-located with the southernmost breakpoint in the current analysis. Winds decreased during the study period but were still in the SaffirSimpson Category 3 range at 1200 UTC 29 Aug., having made landfall 50 minutes earlier. A subsequent landfall occurred near the Louisiana/Mississippi border at 1445UTC on 29 Aug., 45 minutes after the end of the study period. At this time, maximum sustained winds were $54 \mathrm{~ms}^{-1}$ (105kt). During the study period, forward velocity increased from 5.2 to $6.7 \mathrm{~ms}^{-1}$ while the storm began to recurve from a north-northwesterly heading to a northerly heading. Dry air was entrained into the southwestern portion of the storm [1]. Katrina was large in size, with a radius of outermost closed isobar $555-650 \mathrm{~km}$, and radius of gale-force winds (R17) $230-370 \mathrm{~km}$ according to values from the extended best track dataset [23]. This places Katrina in the $90^{\text {th }}$ percentile for the Atlantic basin TCs [24]. Each quadrant exhibited peak values in R17 at 0000 UTC on 29 Aug. Thus, the storm was growing in size at the start of the analysis and contracting in size by the period's end as it approached and moved over land. A fine-scale analysis of the principal rainband of Hurricane Katrina on 28 Aug. was performed for the Hurricane Rainband and Intensity Change Experiment [3] and its results are reported by [25,26].

\section{Defining start of rainfall event}

The first task was to determine when rainfall started at each location. The locations were selected using the National Hurricane Center (NHC)'s breakpoints. These coastal locations are designated points where tropical storm and hurricane watches and warnings commence and/or terminate. Utilizing these breakpoints in this case study allowed the comparison of timing between watch/warning issuance and the start of rainfall and will facilitate analysis of rainfall timing for dozens of TCs in future studies. There were 110 breakpoints along the U.S. Coastline from Eastport, Maine to the Mouth of the Rio Grande River in Texas. This study examined ten breakpoints (Figure 1, Table 1) that received rainfall prior to the landfall of Hurricane Katrina near Buras, LA at 1110 UTC 29 Aug 2005. 


\section{International Journal of Environmental Sciences \& Natural Resources}

Table 1: Breakpoints, day and time of rain event start, distance from TC center at that time, average rainfall, and maximum rainfall over the 6-hr period used to calculate rain event start.

\begin{tabular}{|c|c|c|c|c|c|}
\hline Breakpoint & $\begin{array}{c}\text { Start Day } \\
\text { Hour }\end{array}$ & Time Before Landfall (hr) & Dist. to Center (km) & Avg. 6hr Rain (mm hr-1) & Max. 6hr Rain (mm hr-1) \\
\hline Morgan City, LA & 2905 & 6 & 255 & 3.3 & 5.02 \\
\hline Grand Isle, LA & 2818 & 17 & 350 & 5.04 & 14.99 \\
\hline Mouth Miss. River & 2818 & 17 & 320 & 3.14 & 8.85 \\
\hline Lake Maurepas, LA & 2905 & 6 & 280 & 5.38 & 9.14 \\
\hline Lake Pontchartrain & 2821 & 14 & 400 & 3.49 & 5.26 \\
\hline Mouth Pearl River & 2822 & 13 & 375 & 3.98 & 3.14 \\
\hline Pascagoula, MS & 2900 & 11 & 365 & 3.14 & 6.69 \\
\hline MS/AL border & 2900 & 11 & 385 & 2.46 & 6.86 \\
\hline AL/FL border & 2900 & 11 & 435 & 3.27 & 5.72 \\
\hline Destin, FL & 2902 & 9 & & & 6.5 \\
\hline
\end{tabular}

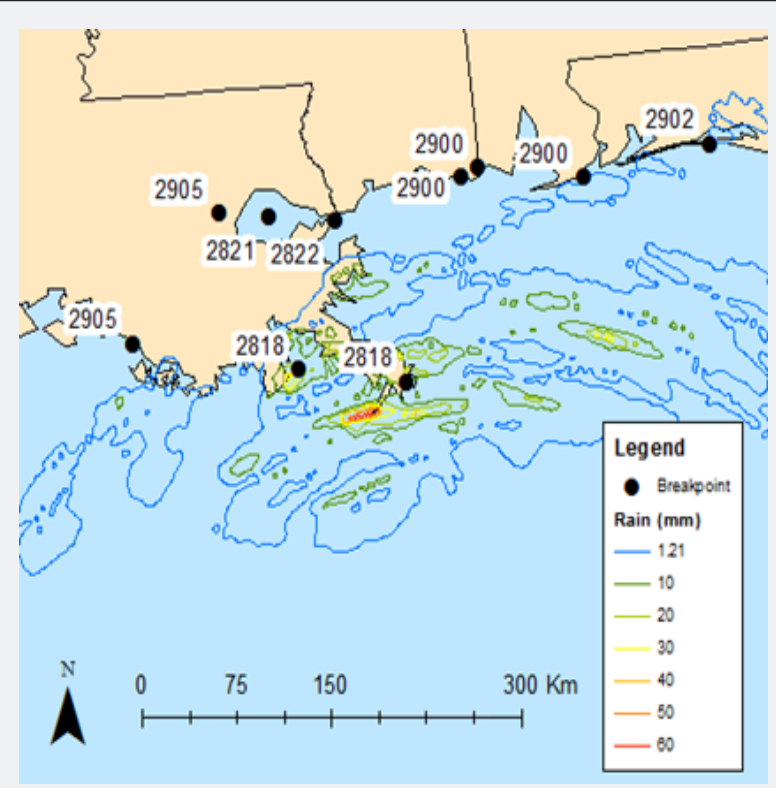

Figure 1: Stage IV one-hour rainfall at 28 Aug. 1800 UTC. NHC breakpoint positions are labelled with day and time of rain event start.

The dataset utilized to examine rainfall was the Stage IV gridded precipitation dataset $[27,28]$. Stage IV data are radar estimates of one-hour precipitation that have been corrected using rain gauge totals and undergo quality control and analysis by personnel at the River Forecast Centers. Thus, using these data offer several advantages over using the One Hour Precipitation product from Weather Surveillance Radar 1988 Doppler (WSR88D) Level III which does not feature corrections by rain gauges. The Stage IV data are gridded every $4 \mathrm{~km}$. The hourly rainfall at each breakpoint was determined by employing a GIS to determine which grid cell in the Stage IV dataset covers the location of the breakpoint. Analysis began at $24 \mathrm{~h}$ prior to landfall and rainfall totals each hour were recorded at each breakpoint.

Upon reviewing the literature, there does not seem to be a widely-accepted rain rate amount and duration threshold to define a rainfall event, particularly from a TC. The Weather Prediction Center produces storm-total rainfall maps using daily data, but a more fine-scale temporal resolution was desired in the current analysis. Previous studies have used radar reflectivity values of 20 and $25 \mathrm{dBZ}$ to define the edges of TC rainbands $[6,10,29]$, and $1.21 \mathrm{~mm} \mathrm{hr}^{-1}$ equates to a $25 \mathrm{dBZ}$ value using the tropical $Z$ to $R$ conversion equation $\left(Z=250 R^{1.2}\right)$ [30]. Therefore, this study subjectively employed a minimum rain rate of $1.21 \mathrm{~mm} \mathrm{hr}^{-1}$ that must be sustained for at least six hours. The rain event start time was the first hour of this qualifying six-hour period.

\section{Measurements of radar reflectivity}

Shifting to the storm-centric analysis of Katrina's outer rainbands, this study used Level II reflectivity data from radars in the WSR-88D network. Radars within $500 \mathrm{~km}$ of the location of Katrina's center during the study period were used to create 
a mosaic. The methodology for creating a mosaic presented in [31] was followed and is summarized briefly here. The mosaic was created by placing values onto a horizontal grid measuring $1 \mathrm{~km} \times 1 \mathrm{~km}$, with vertical resolution of $0.5 \mathrm{~km}$. A weighted interpolation was performed that gives the highest weight to the most recent values from the closest radar to each cell. The mosaic was constructed using data nearest the top of each hour, and data were utilized from a horizontal slice at $3 \mathrm{~km}$ altitude. Once the mosaic was constructed, the grid cells were contoured every $5 \mathrm{dBZ}$ from $20 \mathrm{dBZ}$ to $45 \mathrm{dBZ}$. These contours were then converted into polygon features that have properties including area, perimeter, and a center of mass (or centroid). The position of each centroid was calculated relative to the storm center. As this calculation requires data from a higher temporal resolution that available in HURDAT2, a cubic spline interpolation was performed to identify center positions each hour.

The next step was to locate the center lines for polygons containing reflectivity values of $40 \mathrm{dBZ}$ to identify convective regions indicating that the rainband is in a mature phase. To extract the outermost line at the top of each hour, smaller arcs located within close proximity to one another were joined together to create one larger line. A GIS then computed the start, midpoint, endpoint, and length of lines. The midpoint of the line was used to calculate the distance from the storm center. As the focus of the study is on the leading edge of the storm, analysis began prior to the entire storm being in range of the WSR-88D network. Results are reported each hour 28 Aug. 1800 - 29 Aug. 1400 UTC. After this time, radar data are not available for the main radar that covers the study region, located at Slidell, Louisiana.

\section{Examination of environmental moisture}

The current study explored the moisture surrounding Katrina using precipitable water for the entire atmosphere. These data are available every three hours at a horizontal resolution of $0.25^{\circ}$ latitude and longitude from the North American Regional Reanalysis (NARR) [32]. The selection of this dataset was motivated by $[33,34]$ who found good representation of TC secondary circulation in NARR for locations close to the U.S. In particular, [35] found that Katrina's precipitation fields as measured from NARR data changed shape 24 hours prior to landfall, 6 hours before reaching peak intensity, consistent with structural changes reported in [22]. In the current study, the analysis of TPW data also commenced at 1800 UTC on 28 Aug. and this previous work suggests this is an important time to examine the evolution of Katrina's leading edge.

\section{Results and Discussion}

\section{Rain event timing}

Rainfall began at 1800 UTC on 28 Aug. at the Mouth of the Mississippi River and Grand Isle, LA. The eye of Katrina eventually passed between these two breakpoints, but both were in the right front quadrant at the time that rainfall began, which was
17 hours prior to landfall (Table 1). The latest start time among the 10 breakpoints was 0500 UTC 29 Aug., which occurred at the western-most location of Morgan City, LA. This breakpoint was west of the storm track, and the closest approach of the storm was $160 \mathrm{~km}$. Destin, FL was the easternmost breakpoint and rainfall began here when the TC center was $435 \mathrm{~km}$ away and 9 hours before landfall. The straight-line distance between Morgan City and Destin is $480 \mathrm{~km}$ to help place the span of Katrina's rainfall into perspective. When values are averaged across the 10 breakpoints, rainfall begins $12 \mathrm{~h}$ prior to landfall when the TC center is $353 \mathrm{~km}$ away. Thus, rainfall is likely to have begun much earlier than for a TC of smaller size. Further research is needed to place Katrina's rainfall start times into context with other U.S. landfalling TCs.

The threshold employed to determine the start time of rainfall was the maintenance of $1.21 \mathrm{~mm} \mathrm{hr}^{-1}$ rain rates over a 6 -h period. The average rain rate over this 6 - $\mathrm{h}$ period for the 10 locations was $3.3 \mathrm{~mm} \mathrm{hr}^{-1}$ with a maximum of $7.2 \mathrm{~mm} \mathrm{hr}^{-1}$. The largest hourly total occurred at Grand Isle, LA where $14.99 \mathrm{~mm}$ were received (Table 1). These numbers suggest that the $1.21 \mathrm{~mm} \mathrm{hr}^{-1}$ threshold was a reasonable approximation and provides a starting point for future research.

Hurricane warnings were issued for all breakpoints save Destin, FL where at tropical storm warning was issued instead, at 0300 UTC on 28 Aug. Thus, rainfall began 15-26 hours after the warning was issued. Currently, warnings are issued 36 hours in advance of the predicted onset of tropical storm-force winds. Prior to 2010 however, warnings for tropical storms and hurricanes were issued 24 hours before these threshold wind speeds were expected to occur. Thus, at eight of nine locations expected to receive hurricane-force winds, rainfall did begin before the anticipated onset of hurricane-force winds. It is also notable that rainfall began at some locations prior to the arrival of gale-force winds. Analysis performed by [36] showed that R17 averaged 300 $\mathrm{km}$ in the northern quadrants of Katrina on 28 Aug. Also, [37] show that $17 \mathrm{~ms}^{-1}$ winds had not reached the coastline at the time when the current study determined that rainfall commenced at breakpoints in Mississippi and Alabama. Thus, rainfall can begin several hours before the onset of gale-force winds, which shortens the time to complete preparations before the storm's arrival. Future work will examine more TCs to determine how frequently rainfall begins prior to the onset of gale-force winds.

\section{Measuring rainband leading edge and moisture distribution}

During the 20h period 1800 UTC 28 Aug. - 1400 UTC 29 Aug., five main regions were identified as marking the leading edge of Katrina's rain field. At the first analysis time, the Lead closest to land (Lead A) was oriented southwest-to-northeast near the mouth of the Mississippi River (Figure 2). It extended farther towards the southwest on its left side and extended more towards the east on its right side. The midpoint of Lead A moved $250 \mathrm{~km}$ northwest before it eroded (Figure 3), and its eastern edge dissipated quickly 
as it crossed land. With an average speed of $22.5 \mathrm{~ms}^{-1}$, it had the fastest motion of the five leading edges, and it moved away from the circulation center after crossing land (Figure 3). Lead C moved in a similar direction $9 \mathrm{~h}$ later at a slower speed of $15 \mathrm{~ms}^{-1}$. It had the shortest length of the five edges and it did not extend as far west as Lead A, yet it eroded in a similar location. It formed and remained at a distance closer to the storm center when compared with Lead A. Leads C, D, and E formed progressively closer to the storm center than the earlier Leads A and B.

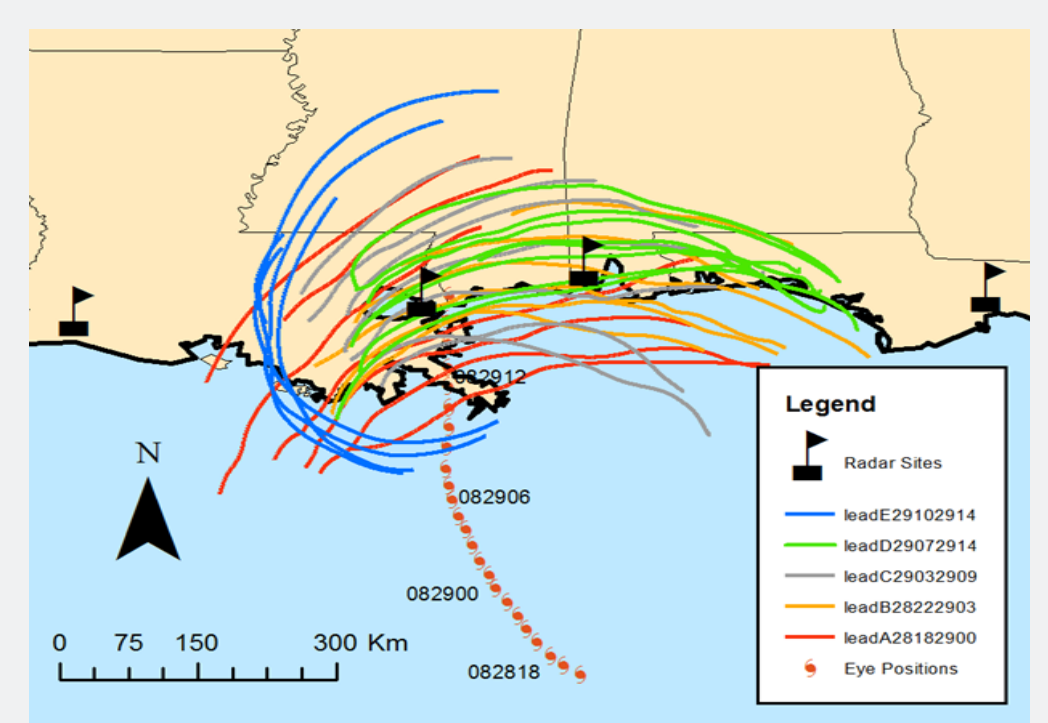

Figure 2: Positions of the leading edges each hour for the outer rainbands. Legend labels indicate day and hour of band formation and dissipation, with Lead A forming and dissipating earliest, and E forming the latest. TC centers are interpolated to each hour.

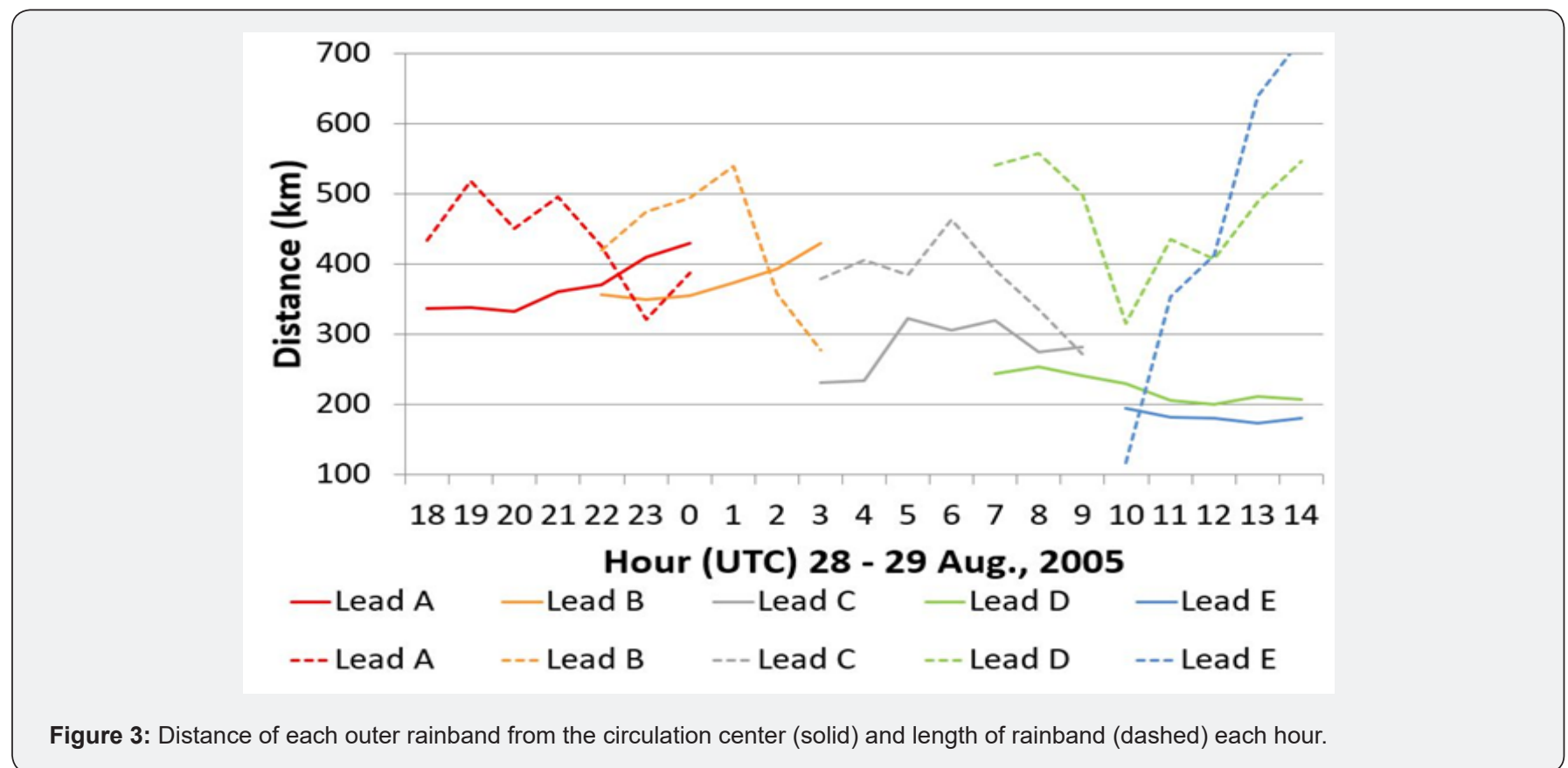

Lead B was identified beginning at 2200 UTC 28 Aug. and became the outermost rainband three hours later. Rather than moving northwest as did Lead A, Lead B moved towards the north at $14.4 \mathrm{~ms}^{-1}$. Like Lead A, it propagated outward after its midpoint crossed land and it decreased in length (Figure 3). However, it eroded from the west rather than from the east as was the case with Lead A. Lead D developed 9 hours later at 0700 UTC 29 Aug. in a location similar to B along the Mississippi/Alabama coastline (Figure 2). It traveled the shortest distance of $110 \mathrm{~km}$ but had the longest length when it first developed exceeding $525 \mathrm{~km}$ (Figure 
3). Its forward motion was slower than the preceding Leads with an average of $12.5 \mathrm{~ms}^{-1}$. It ended up closer to the storm center than when it began.

Whereas Leads A, B, C, and D had a general orientation that was west to east, Lead E took shape $180 \mathrm{~km}$ west of the eye with a north to south orientation. After forming at 1000 UTC 29 Aug., it wrapped more than $180^{\circ}$ around the eye within 4 hours, growing in length each hour to become the longest rainband spanning $700 \mathrm{~km}$ (Figure 3). Like D, it moved slowly at $12.4 \mathrm{~m} \mathrm{~s}^{-1}$. Despite its growth in extent, it maintained its distance from the eye and its central section remained over Morgan City and Baton Rouge, Louisiana.
Two main findings emerge upon inspection of the data across the five rainbands. The first finding is that earlier rainbands were located at a farther distance from the eye (A, B) and moved outwards as they decreased in length (Figure 3). Data from the NARR show that TPW also expanded (Figure $4 \mathrm{a} \& 4 \mathrm{~b}$ ), and data from the EBT show that the ROCI increased from 555-650km while gale-force winds also expanded during the existence of these rainbands. Lead $\mathrm{A}$ formed in a region where TPW values were $62 \mathrm{~mm}$ (Figure $4 \mathrm{a}$ ), and it dissipated in an area where a gradient existed from 65 to $55 \mathrm{~mm}$ spanning $100 \mathrm{~km}$ (Figure 4b), yielding a rate of change of $1 \mathrm{~mm}$ per $10 \mathrm{~km}$. Lead $B$ remained in $62.5 \mathrm{~mm}$ values throughout its existence.
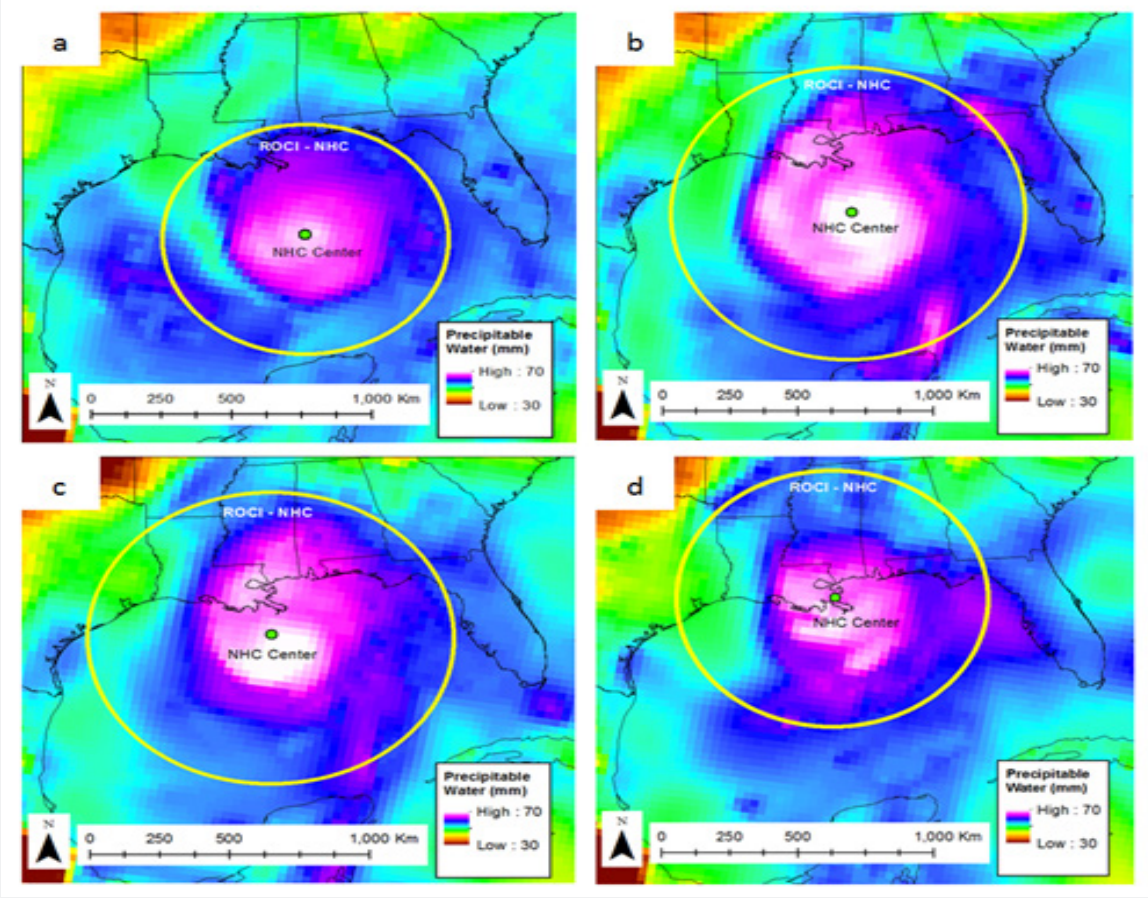

Figure 4: Precipitable water from NARR at a) 28 Aug. 1800, b) 29 Aug. 0000, c) 29 Aug. 0600, and d) 29 Aug. 1200 UTC. Position of center and radius of outermost-closed isobar $(\mathrm{ROCl})$ reported by $\mathrm{NHC}$ are indicated.

Secondly, after 0400UTC, the rainbands no longer moved away from the storm center. Leads C, D, E formed 300-180 km from the center of circulation and remained at this distance. However, D and $\mathrm{E}$ grew longer. Like Lead B, Leads $\mathrm{C}$ and $\mathrm{D}$ stayed in the region containing $62.5 \mathrm{~mm}$ of TPW (Figure 4c). Rainbands arcing along the Mississippi/Alabama coastline moved slowest at first, then moved faster after crossing the coastline as convection weakened. The increased friction at the coastline might have played a role in slowing forward progress while the storm center was increasing its forward velocity. Additional studies should explore jointly the roles of frictional convergence and moisture gradients. Lead $\mathrm{E}$ did not expand outward but remained at a similar distance west of the storm track. It also remained near $65 \mathrm{~mm}$ precipitable water values that formed a gradient $65-45 \mathrm{~mm}$ spanning $200 \mathrm{~km}$ (Figure $4 \mathrm{~d}$ ). That is a change of $1 \mathrm{~mm}$ per $10 \mathrm{~km}$ as was observed previously. It is an interesting observation that this was the only outer band that grew in extent as it remained nearly stationary.

Examination of the TPW data show that the core of the storm contained values of $70 \mathrm{~mm}$ with $60 \mathrm{~mm}$ delineating the outer edge of the storm. This agrees with previous research that higher values of TPW can be associated with larger TCs. Low values near $30 \mathrm{~mm}$ are apparent in the northwest corner of the images in Figure 4 
and are associated with the eastward-moving trough that aided in Katrina's transition into an extratropical cyclone. A gradient existed west of Katrina's circulation that strengthened throughout the study period. Two of the rainbands that formed along the leading edge of Katrina's circulation that had centroids left of the storm's track exist on the inside of a moisture gradient of $1 \mathrm{~mm}$ per $10 \mathrm{~km}$. The ability of NARR to represent atmospheric moisture is somewhat limited given its horizontal resolution of $32 \mathrm{~km}$ compared with the $1 \mathrm{~km}$ radar mosaic. The NARR cannot resolve such localized features as cool pools from downdrafts in convective cells. However, the confluence of Katrina's counterclockwise circulation on its left side with the drier air from the continental air mass and baroclinic zone could be responsible for this gradient that appears to limit rain field expansion outward. Examination of specific humidity data from NARR (not shown) depicted the driest air, and therefore sharpest contrast between Katrina's circulation and the surrounding air mass, to occur in the middle troposphere at $500 \mathrm{hPa}$. Research by [18] measured the distance between the storm center and the nearest point on a contour line denoting $40 \mathrm{~mm}$ of TPW to determine how close a dry air mass existed from the storm center in their 43 Gulf Coast TCs. Results from the current study suggest that it is also important to identify gradients in moisture. Thus, future research should identify gradients in moisture between TCs and their surrounding environments to determine if the differing densities in these regions could help to enhance rainband formation initially, but then limit their ability to produce high rain rates given the diminished supply of moisture and the stable atmospheric environment.

\section{Conclusion and Future Research}

This study utilized multiple datasets derived from radar reflectivity values to examine the rainbands that defined the leading edge of Hurricane Katrina (2005) as it approached and moved over the U.S. Gulf coastline. Observations were made from land-based and storm-based perspectives: 1) defining the time that rainfall began along the coast through analysis of hourly rainfall totals, and 2) measuring the size and position of the leading outer rainband of the storm according to reflectivity values from ground-based radar. The time that rainfall began was determined first. Using a minimum rain rate of $1.21 \mathrm{~mm} \mathrm{hr}^{-1}$ sustained for at least six hours to define a rainfall event, it was observed that rainfall commenced an average of 12 hours prior to landfall at ten different locations along the coast. At the time of rainfall start, the storm center was an average of $353 \mathrm{~km}$ away from each location. Rainfall onset occurred 15-26 hours after a tropical storm or hurricane warning was issued, which at the time, meant that those wind speeds were expected to occur within 24 hours. Rainfall began prior to the arrival of gale-force winds at some locations.

The spatial analysis of Katrina's leading rainbands over a $20 \mathrm{~h}$ period yielded five different bands that contained $40 \mathrm{dBZ}$ reflectivity values and they were tracked for 4-7 hours each.
The first two leading edges (A and B) formed 4 hours apart and were of similar length and about $350 \mathrm{~km}$ from the storm center with motion away from center. However, A moved towards the northwest while B moved towards the north. Lead C formed 9 hours after Lead A and closer to the storm center, but also moved outwards and towards the northwest. Leads D and E did not propagate outwards from the storm center and both grew in length although on different sides of the storm. While Lead D grew towards the east, Lead E remained west of the storm center. Examination of TPW values show that $60 \mathrm{~mm}$ corresponded with the outer edge of the storm, with a $1 \mathrm{~mm}$ decrease each $10 \mathrm{~km}$ occurring on the western side of the storm where Leads A and E dissipated. Values of TPW were high for Katrina compared with other landfalling TCs in the region reported in previous studies, and since Katrina was also larger in size than the average TC, this study supports previous work suggesting that environments with high moisture can support larger TCs.

Future work will further explore moisture gradients along the outer edges of TC circulations as they approach and move over land. This will facilitate ongoing efforts to explore the growth and decline of rainfall regions of landfalling TCs. Additional reflectivity threshold and duration requirements to define a rain event will also be tested with the aim to develop statistical models to associate the various environmental conditions within which TCs exist during landfall with the variations in timing of the start of rainfall. Work will also be undertaken to estimate when R17 crosses land and explore the environmental conditions under which rainfall commences hours prior to this time.

\section{Acknowledgement}

Ian Comstock, Jingyin Tang, and Stephanie Zick contributed preliminary data to this project, for which the bulk of analysis was performed in 2015 and was funded at that time by the National Science Foundation Award 1053864.

\section{References}

1. Graumann, A, Houston, TG, Lawrimore, JH, Levinson, DH, Lott, N, et al. (2006) Hurricane Katrina: A climatological perspective: Preliminary report National Climatic Data Center (U.S.) no. 2005-01.

2. Jiang H, Ramirez EM, Cecil DJ (2012) Convective and rainfall properties of tropical cyclone inner cores and rainbands from 11 years of TRMM data. Mon Wea Rev 141(2): 431-450.

3. Houze RA, Chen SS, Lee WC, Rogers RF, Moore JA, et al. (2006) The hurricane rainband and intensity change experiment. Bull Amer Meteor Soc 87(11): 1503-1518.

4. Willoughby HE, Marks FD, Feinberg RJ (1984) Stationary and moving convective bands in hurricanes. J Atmos Sci 41(22): 3189-3211.

5. Yu CK, Lin CY, Luo JS (2019) Tracking a long-lasting outer tropical cyclone rainband: Origin and convective transformation. J Atmos Sci 76(10): 3267-3283.

6. Cecil DJ, Zipser EJ, Nesbitt SW (2002) Reflectivity, ice scattering, and lightning characteristics of hurricane eyewalls and rainbands. Part I: Quantitative description. Mon Wea Rev 130(4): 769-784. 
7. DeMaria M, DeMaria RT, Knaff JA, Molenar D (2012) Tropical cyclone lightning and rapid intensity change. Mon Wea Rev 140(6): 1828-1842.

8. Guinn TA, Schubert WH (1993) Hurricane spiral bands. J Atmos Sci 50(20): 3380-3403.

9. Matyas CJ (2009) A spatial analysis of radar reflectivity regions within Hurricane Charley (2004). J Appl Meteorol Climatol 48(1): 130-142.

10. Barnes GM, Zipser E, Jorgensen D, Marks FD (1983) Mesoscale and convective structure of a hurricane rainband. J Atmos Sci 40(9): 21252137.

11. Hence DA, Houze RA (2012) Vertical structure of tropical cyclone rainbands as seen by the TRMM precipitation radar. J Atmos Sci 69(9): 2644-2661.

12. Li Q, Wang Y (2012) A comparison of inner and outer spiral rainbands in a numerically simulated tropical cyclone. Mon Wea Rev 140(9): $2782-2805$

13. Trenberth KE, Davis CA, Fasullo J (2007) Water and energy budgets of hurricanes: Case studies of Ivan and Katrina. J Geophys Res Atmos 112(D23): 11.

14. Jiang HY, Halverson JB, Zipser EJ (2008) Influence of environmental moisture on TRMM-derived tropical cyclone precipitation over land and ocean. Geophys Res Lett 35(17).

15. Hill K, Lackmann, GM (2009) Influence of environmental humidity on tropical cyclone size. Mon Wea Rev 137(10): 3294-3315.

16. Matyas CJ, Cartaya M (2009) Comparing the rainfall patterns produced by Hurricanes Frances (2004) and Jeanne (2004) over Florida. Southeastern Geographer 49(2): 132-156.

17. Rodgers EB, Pierce HF (1995) Environmental influence on TyphoonBobbie precipitation distribution. J Appl Meteor 34(11): 2513-2532.

18. Kim S, Matyas CJ, Yan G (2020) Rainfall symmetry related to moisture, storm intensity, and vertical wind shear for tropical cyclones landfalling over the US Gulf coastline. Atmosphere 11(9): 895.

19. Parrish JR, Burpee RW, Marks FD, Grebe R (1982) Rainfall patterns observed by digitized radar during the landfall of Hurricane Frederic (1979). Mon Wea Rev 110(12): 1933-1944.

20. Blake ES, Landsea CW, Gibney EJ (2011) The deadliest, costliest, and most intense United States torpical cyclones from 1851 to 2010 (and other frequently requested hurricanes facts) National Hurricane Center NOAA Technical Memorandum NWS NHC-6.

21. Chan SC, Misra V (2010) A diagnosis of the 1979-2005 extreme rainfall events in the southeastern United States with isentropic moisture tracing. Mon Wea Rev 138(4): 1172-1185.

22. Beven JL, Avila LA, Blake ES, Brown DP, Franklin JL, et al. (2008) Atlantic hurricane season of 2005. Mon Wea Rev 136(3): 1109-1173.

23. Demuth JL, DeMaria M, Knaff JA (2006) Improvement of advanced microwave sounding unit tropical cyclone intensity and size estimation algorithms. J Appl Meteorol Climatol 45(11): 1573-1581.

24. Kimball SK, Mulekar MS (2004) A 15-year climatology of North Atlantic tropical cyclones. Part I: Size parameters. J Climate 17(18): 3555-3575.

25. Hence DA, Houze RA (2008) Kinematic structure of convective-scale elements in the rainbands of Hurricanes Katrina and Rita (2005). J Geophys Res Atmos 113(D15): 20.

26. Didlake AC, Houze RA (2009) Convective-scale downdrafts in the principal rainband of Hurricane Katrina (2005). Mon Wea Rev 137(10): 3269-3293.

27. Fulton RA, Breidenbach JP, Seo DJ, Miller DA, O’Bannon T (1998) The WSR-88D rainfall algorithm. Wea Forecasting 13(2): 377-395.

28. Lin Y, Mitchell KE (2005) The NCEP stage II/IV hourly precipitation analyses: Development and applications. 19th Conference on Hydrology.

29. Marks FD (1985) Evolution of the structure of precipitation in Hurricane Allen (1980). Mon Wea Rev 113(6): 909-930.

30. Rosenfeld D, Wolff DB, Atlas D (1993) General probability-matched relations between radar reflectivity and rain rate. J Appl Meteor 32(1): 50-72.

31. Tang J, Matyas CJ (2016) Fast playback framework for analysis of ground-based Doppler radar observations using Map-Reduce technology. Journal of Atmospheric and Oceanic Technology 33(4): 621-634.

32. Mesinger F, DiMego G, Kalnay E, Mitchell K, Shafran PC, et al. (2006) North American regional reanalysis. Bull Amer Meteor Soc 87(3): 343360 .

33. Zick SE, Matyas CJ (2015) Tropical cyclones in the North American Regional Reanalysis: The impact of satellite derived precipitation overocean. Journal of Geophysical Research Atmospheres 120(17): 87248742.

34. Zick SE, Matyas CJ (2015) Tropical cyclones in the North American Regional Reanalysis: An assessment of spatial biases in location, intensity, and structure. Journal of Geophysical Research Atmospheres 120(5): 1651-1669.

35. Zick SE, Matyas CJ (2016) A shape metric methodology for studying the evolving geometries of synoptic-scale precipitation patterns in tropical cyclones. Annals of the Association of American Geographers 106(6): 1217-1235.

36. Guo Q, Matyas C (2016) Comparing the spatial extent of Atlantic basin tropical cyclone wind and rain fields prior to land interaction. Physical Geography 37(1): 5-25.

37. McTaggart Cowan R, Bosart LF, Gyakum JR, Atallah EH (2007) Hurricane Katrina (2005) Part I: Complex life cycle of an intense tropical cyclone. Mon Wea Rev 135(12): 3905-3926. 
Your next submission with Juniper Publishers will reach you the below assets

- Quality Editorial service

- Swift Peer Review

- Reprints availability

- E-prints Service

- Manuscript Podcast for convenient understanding

- Global attainment for your research

- Manuscript accessibility in different formats ( Pdf, E-pub, Full Text, Audio)

- Unceasing customer service

Track the below URL for one-step submission https://juniperpublishers.com/online-submission.php 